Discussion Paper No. 46

Williams Project on the Economics of Higher Education

Denison Gatehouse

Williams College

Williamstown, MA 01267

\title{
A Guide to Measuring College Costs
}

\author{
Gordon C. Winston \\ Williams College
}

January, 1998

DP-46

Note: This paper is intended for private circulation and should not be quoted or referred to in publication without the permission of the authors. Funding for this paper was provided by the Andrew Mellon Foundation through the Williams Project on the Economics of Higher Education. 


\title{
A Guide to Measuring College Costs
}

\author{
Gordon C. Winston \\ Williams College
}

This paper reviews the major conceptual and practical problems that emerge in estimating the cost of producing a year of undergraduate education. The three major areas discussed are the complicated issues in estimating the yearly cost of physical capital (the cost of using land, buildings, and equipment), the treatment of student financial aid (as a legitimate cost of producing education or simply a price discount), and the cost allocation problems inherent in separating out those costs generated by undergraduate education in a complicated "multi-product" university. 
January, 1998

\title{
A Guide to Measuring College Costs
}

\author{
Gordon C. Winston* \\ Williams College
}

In principle, measuring the average cost of providing a year of undergraduate education at a school is simple: add up its total undergraduate educational costs and divide by the number of undergraduates. But in fact, there are issues of concept and data that make it anything but simple. Three things cause major problems:

- the costs of using buildings, equipment, and land are both large (25-40\% of total cost) and badly reported in college accounts

- it's not at all clear whether financial aid grants are a cost of education or a simple price-discount ${ }^{1}$

- since colleges and, especially, universities do other things than educate undergraduates, there are major questions of cost allocation and joint costs that have to be worked through to get to undergraduate costs.

The capital cost and financial aid problems are there for all schools while cost allocation is more a problem for complicated universities than for simple liberal arts colleges - in fact, Williams and Swarthmore and Carleton don't seem to have that problem at all.

The purpose of this note is to describe what's been learned in doing a fair amount of college cost estimation, both for individual schools from their own financial records and for the whole of higher education using US Department of Education (IPEDS) data. Those estimates have both generated educational costs, per se, and provided a major raw

* Comments from Jared Carbone and Larry Litten and Jim Roberts on an earlier draft were especially helpful. 
material for the estimation of student subsidies. So most of what's described here has appeared in various earlier papers ${ }^{2}$ but it seems useful to bring it together in one place.

It's surprisingly complicated, conceptually, to compute these costs, especially for those well trained in college fund accounting for whom it requires a new and unfamiliar mental model. To sort the issues out, initially, I had to go back to first principles and the economists of the 1930s and 1950s who were working carefully through the fundamentals of economic information (accounting) for for-profit firms - to Sir John Hicks and Henry Simons and Trgve Havaalmo and others - and merge that with the insights of recent students of nonprofit firms like Henry Hansmann. And my earlier incarnation as a capital theorist, fretting about the way we understand the role of physical capital in for-profit production, proved unexpectedly helpful.

So there are two kinds of problems in calculating college costs - understanding a conceptual framework that's different from both the familiar accounting in for-profit firms and the fund accounting that's only now being abandoned in non-profits and, more pragmatically, finding the numbers that can be used actually to measure costs. Those who have tried to generate reliable figures have found an audience whose conceptual hangups create serious barriers to accepting their figures, especially those describing the costs of the services of buildings and equipment and land, of physical capital. As is so often the case in the economics of higher education, what's sensible to even well informed people can be dead wrong while what's accurate is counter-intuitive. So it may be most helpful in what follows if I first briefly lay out the Ideas that inform the methodology and then the Procedures for getting the numbers. Under Ideas, I'll try to suggest ways to frame or describe the issues that might help skeptics appreciate why an unfamiliar framing is necessary to calculate college costs. And I'll attach the "Statements of Activities" page from Williams' 1996 Financial Report and a spreadsheet that uses those numbers to generate the appropriate per-student costs in order to give the issues some concreteness.

\footnotetext{
${ }^{1}$ See Bowen-Breneman, Rothschild-White, Winston DP-40.
} 
Current operating costs obviously capture much of what's relevant, so I'll start there in Part A, but in even the simplest school, they have to be adjusted by removing costs that are irrelevant to education. Some such costs are clear cut but some aren't. It's necessary to decide whether financial aid "costs" are relevant or not - whether they're really costs of educational production, as in our accounting conventions, or, as is increasingly popular, simply price-discounts that have nothing to do with real educational production. Then there are the entries that capture bits and pieces of the costs of using capital interest payments and depreciation - but do it so partially and inconsistently that it's best to replace them with coherent and consistent estimates of the current cost of using buildings and equipment and land. (Though this will become a bit more complicated under the new accounting standards of FASB 117, as noted below, it will still have to be done.) And some costs are typically included in operating costs - under operations and maintenance - that are legitimate educational costs, but describe capital investment for the future, rather than current costs for the present year. Then there's the whole complicated issue of how much of these total costs should be allocated to undergraduate education and how much to other activities and, finally, how many full time equivalent undergraduates there are in a school that has a significant part-time enrollment.

Part B is the longest, tackling the estimation of capital service costs, while Part C discusses, far more briefly, cost allocation in a multi-product university. Parts $\mathrm{E}$ and $\mathrm{F}$ touch on student FTEs - the denominator - and the calculation of student subsidies while Part G and the two tables it refers to illustrate all this using Williams 1996 data.

\section{A. Operating Costs}

Three modifications are needed to adjust the line "Total operating expense:"

\footnotetext{
${ }^{2}$ In the bibliography at the end, see especially Williams Project Discussion Papers numbered 14, 15, 22, $23,32,40$, and 41 for these discussions.
} 
- some entries need to be subtracted off either because they're irrelevant to undergraduate education (Life income payments for instance) or because they are to be replaced by more careful calculations (Depreciation and Interest on indebtedness),

- Scholarships and fellowships raise the question about whether they are costs of education or a price discount, and

- reported costs of Operation and maintenance of plant usually contains some spending that is strictly an operating cost along with some that is, instead, a capital investment.

\section{1 - Irrelevant expenditures and those to be calculated more carefully}

Life income payments, as noted, have little to do with the current costs of producing education, however much they may serve its future financing. Interest on indebtedness, similarly, is a matter of financial management (and a complicated and interesting one involving arbitrage income for wealthy institutions). To the extent that such interest charges represent part of the real "cost of funds" or "opportunity cost of physical capital" that is a legitimate current cost of production, they are captured in the more systematic estimates of those capital service costs described below. So their partial reporting is eliminated from current costs in order to replace it with the complete estimate of capital costs described in the next section.

\section{$\underline{2-\text { Scholarships and fellowships }}$}

\section{The idea:}

If a school uses financial aid grants to increase student demand and fill seats and beds, they're clearly a price discount and should be eliminated from costs and subtracted from gross tuition and fee revenue to reflect what the school actually earns in tuition and fees. Financial aid is not a cost. This is contrary, of course, to what college accounting does - which is to charge all students the full sticker price, then, in effect, to hand some of them money with which to pay all or part of that charge. A car dealer, in contrast, sensibly recognizes as sales revenues only what he actually gets from his customers as sales revenues, after - net of - any price-shading. 
But for some schools, it's not that simple. It's recently been argued by economists ${ }^{3}$ that quality higher education operates with a "customer-input technology" where peereffects importantly contribute to a student's education: good students educate good students. In those schools, then, financial aid is much like faculty salaries in that it pays for student quality which is an input to educational production. To the extent that this is true, financial aid payments are indistinguishable from any other payment to a productive input like heating oil or administrative or faculty salaries. So Fellowships and Scholarships should be counted as a cost of education.

\section{Procedures:}

Unfortunately, either can be right, depending on the role financial aid plays in the functioning of the school - it can be pure price discount or it can be the payment for a factor of production. For IPEDS data that covers all sorts of schools, I've assumed that financial aid more often than not represents a price discount so I've always subtracted it from legitimate educational costs, and I think that's probably the right thing to do. But among selective schools with long queues of applicants, financial aid improves the average quality of their students through the power of peer effects. So it can be considered a legitimate cost that buys an important input to their production of education. Note that treating financial aid as a cost of production also implies that grant aid is a legitimate income payment to the financial aid student - that he or she earns the financial aid by providing the college with something it uses in its production, whether it's work in the dining hall, line-backer talents, or the supply of peer quality. Under these circumstances all students actually do pay the sticker price, partly in cash, partly in kind.

When in doubt, I'd suggest calling financial aid a price discount and not a legitimate production cost. My reasons are timidity and a desire for uniformity - most schools, by far, use aid as price discount and until the recognition of peer-inputs catches on, it will be hard to defend. Too, it's probably wise to save persuasive energy for the much more important issues of adequately accounting capital service costs. (And since it doesn't

\footnotetext{
${ }^{3}$ Rothschild and White, and DP-40.
} 
matter to the calculation of subsidies whether financial aid is or is not added to both sides of the difference that defines them, I'm particularly tempted to avoid the squabble.) It is important, though, to be clear and explicit and report the size of financial aid, if it is included as a cost, so others can subtract it off for comparability.

\section{$\underline{3-\text { Operation and maintenance }}$}

The idea:

Operation and maintenance of plant is reported as a current expenditure, and much of it is. But in many schools, it includes - beside things like heating oil and janitorial service and building management - significant "renovation and repair" spending that offsets real depreciation and serves, therefore, the same long-term role as new capital investment. That renovation and repair part should be subtracted from the year's operating costs and added, instead, to the year's new capital investment.

\section{Procedure:}

With access to the facilities managers who can estimate how much of reported Operations and maintenance spending is a genuine yearly operating cost and how much of it is a durable investment, the latter can be eliminated from current costs and added to capital investment. But absent that information, no serious error is likely to be introduced by counting all of Operation and maintenance as a current educational cost since it is usually small, relative to other costs. ${ }^{4}$

\section{B. The Cost of Using Physical Capital}

This is the worst issue - conceptually and practically - in the calculation of educational costs because it is huge and neither for-profit nor nonprofit accounting prepares us (or the critics) for its careful incorporation. Indeed, under the rules of fund accounting, the financial accounts often described colleges and universities as if they

\footnotetext{
${ }^{4}$ The larger error - that can accumulate over time - will be found in the accounting of physical capital wealth alluded to later.
} 
taught their classes and held their labs outdoors in (borrowed) vacant lots with no equipment - no recognition of the role or the cost of buildings and land and equipment was required. The new standards of FASB 117 that apply to private colleges and universities move in the right direction, but not far enough to make the problem a trivial one. The neglect of capital distorts calculated educational costs by $25-40 \%$.

\section{The ideas:}

All sorts of things mess up our understanding of the costs of capital services in production: unlike labor or office supplies that are bought from outsiders at a price, the services of buildings, equipment, and land often come from capital stocks owned by the college itself; capital is durable, purchased at a considerable cost in one year for use over future years; inflation changes the value of a building without regard to its condition or use or the services it yields; capital wears out through use and the elements and obsolescence so its value depreciates over time without regular maintenance spending to offset it; resources - "funds" - that have been devoted to buying physical capital are "locked up" and unavailable for a long time either for alternative uses or to earn a financial return. And, finally, a careful accounting of capital costs and capital wealth isn't necessary in the for-profit firms that dominate the economy both because returns to capital and returns to entrepreneurial risk taking are lumped together under what Econ 101 instructors take pains to call "accounting profits" and because a market in the firms, themselves, reflects the value of their physical assets.

Luckily, a lot of thoughtful attention was given to all this by earlier economists even though little has made its way into college accounting conventions. That attention does, though, give us a coherent basis for generating reasonable and consistent estimates of the costs of capital services in education. That they don't ring immediate and familiar bells makes it harder to gain acceptance for those estimates ${ }^{5}$ but they are, nonetheless, essential.

\footnotetext{
${ }^{5}$ Or maybe it recommends some sensible vagueness in how, exactly, the costs of capital are estimated - see Carleton's description in "Assuring Excellence."
} 
The value of the capital services used in production is unambiguously described by a "rental rate" - what a college would have to pay in a competitive market to use its buildings, land, and equipment for a year if they were owned by someone else. The components of the rental rate are (a) the current replacement value of the capital stock (b) the real economic depreciation it suffers during the year, and (c) the opportunity cost of tying up resources in that form for the year. The rental rate, symbolically, is $\mathrm{P}_{\mathrm{k}} \mathrm{K}(\delta+\mathrm{r})$ where $\mathrm{P}_{\mathrm{k}} \mathrm{K}$ is the current replacement value of $\mathrm{K}$ of capital stock, $\delta$ is the yearly rate of depreciation and $\mathrm{r}$ is the 'cost of funds' or 'opportunity cost' of tying up resources in the form of physical capital for the year. ${ }^{6}$

\section{Procedure:}

These three components of yearly capital costs can be estimated fairly reasonably and used to replace the partial accounting of capital costs reported in conventional financial statements (and IPEDS). So the procedure is (a) to eliminate from operating expenditures all reported values of depreciation and interest on indebtedness (for building) and (b) to replace them with a full "yearly cost of capital services" as a computed rental rate.

\section{1 - The current replacement value of the capital stock}

\section{The ideas:}

The major problem here, of course, is that accounting conventions report the value of a school's physical capital stock by adding together historic or book values - what each building or piece of land or equipment cost when it was originally purchased - with no attempt to account for changes in the prices of those things since then. The result is a jumble of costs of buildings and land and equipment, some in prices prevailing in the 1890s, some from 1996, from 1950, and so on. Every campus has its bizarre examples at Williams a nice little faculty house with two bedrooms is carried on the books at $\$ 850$ because that's what it cost to build early in the century. In book values, apples are added

\footnotetext{
${ }^{6}$ When deferred maintenance is considered, it's clear that with DM of accumulated deferred maintenance, a year's rental rate is $\mathrm{P}_{\mathrm{k}} \mathrm{K} \delta+\left(\mathrm{P}_{\mathrm{k}} \mathrm{K}-\mathrm{DM}\right) \mathrm{r}$ since past failure to spend to maintain the capital stock's replacement value has released funds for other uses, leaving only a "net physical capital wealth," $\mathrm{P}_{\mathrm{k}} \mathrm{K}-\mathrm{DM}$, still tied up.
} 
to oranges and flounder and new tires. Interestingly, of the two dozen or so financial statements I've looked at recently, Harvard remains the only school to report the replacement value of its capital stock.

\section{Procedures:}

Estimating replacement values for capital stocks to use as a substitute for the reported book values is fairly straightforward for an individual school. (And as with so much else in college's treatment of the costs of using capital, the present use of historical book values is so bad that estimates of replacement values can be pretty crude and still represent a major improvement.) Facilities managers can tap insurance records for current replacement values of buildings and equipment and estimates can be made for replacement value of land and improvements. Some campuses have got engineering appraisals of replacement values. Consensus estimates of current replacement costs will generate useable numbers if all else fails. Updating these figures after one year's careful estimates can be done by tracking the value of new investment and changes in the construction price index. In the IPEDS survey, replacement values are requested and most schools do report but for some it was necessary to estimate them from book values or E\&G spending (again, details are reported in the Appendix to DP-32).

\section{$\underline{2-\text { Depreciation }}$}

\section{The ideas:}

The idea that a capital stock is worn out by use, deteriorates through time, and loses value through obsolescence is not at all unusual though the use of that fact as a vehicle for important tax advantages in business has pushed the measurement of depreciation pretty far away from its basic economic rationale. (Indeed, when I started out on all this ten years ago, I was told by a college comptroller that colleges didn't have depreciation because they didn't pay taxes.) But the new FASB 117 accounting procedures take the important step of requiring colleges to estimate yearly depreciation and include it as a

But the whole of the capital stock, $\mathrm{P}_{\mathrm{k}} \mathrm{K}$, non the less depreciates each year. See the appendix of DP-32 on this. 
cost of operation. The only problem remaining is that the base for that estimate is the highly understated book value of capital. Note that depreciation is intended to capture the actual decline in value during the year, absence maintenance spending, not the present value of anticipated possible future loss from events like fires.

\section{Procedures:}

Depreciation is reflected in the rental rate as a yearly percent of the replacement value of the capital stock. That rate can be developed from considerable detail, using different rates (useful life estimates) for different types of capital (see, for instance, Probasco) or it can be done more simply as an average over the aggregate of all of the school's capital. In both the individual school estimates and those for IPEDS, I've used $2.5 \%$ of replacement value (from Dunn) and that, reassuringly, is just about what Harvard's very thoughtful procedure works out to. Of course, a larger percentage rate can arbitrarily be applied to understated book values to back into much the same numbers - as Williams seems to have done in 1996 - but that procedure has little underlying rationale and if it's right, it's lucky.

\section{$\underline{3 \text { - The opportunity cost of capital or "the cost of funds" }}$}

\section{The idea:}

This is far and away the stickiest component of the idea that a rental rate measures the current cost of capital services. It will often prove elusive or even counter-intuitive to non-economists in administrations and faculties as it does to Econ 101 students when they first meet the idea in Fall semester. ${ }^{7}$ At base, it's pretty simple: the real resources funds - that were used to build a building could be in use elsewhere if they weren't tied up there. Specifically, they could have been used to buy financial assets that would pay a yearly return: if you don't build a $\$ 1 \mathrm{~m}$. building, you've got $\$ 1 \mathrm{~m}$. to put into the stock market to earn (these days) $\$ 250,000$ in the year. So if you do use it in the building, you have to recognize what you're giving up - the yearly earnings that that use precludes, the 
$\$ 250,000$. If you don't recognize that cost - if you recognize only depreciation costs you're kidding yourself about the actual cost of using capital in education.

One thing we don't want to involve in the idea of opportunity cost is that it depends on who owns the capital stock - our measure of the cost of education should not be affected by ownership - yet conventional reporting leads to that mistake. Take two absolutely identical schools doing exactly the same thing, each with, say, $\$ 500 \mathrm{~m}$. in wealth. In one school, all that wealth is in the form of financial assets on which it earns an income that it uses to, inter alia, rent its $\$ 250 \mathrm{~m}$. campus from somebody else. The other school has made a different portfolio decision - it has $\$ 250 \mathrm{~m}$. in financial assets and owns its own, identical, $\$ 250 \mathrm{~m}$. campus. The costs of education in these two identical schools should be the same - and it will be with an appropriate recognition of the opportunity cost of owning physical capital.

But, it might be objected, schools typically own part of their capital stock outright but have taken out loans against another part. That's why "Interest on indebtedness" shows up as an operating cost in financial accounts.

True, and that fact has two consequences. One is that since the proportion of the capital stock against which debt has been issued will vary from one campus to another (and one set of state laws and agencies to another) comparability between schools - and for a single school over time - will best be served by replacing all such interest payments with consistently estimated opportunity costs. The other consequence is that for schools with endowments, borrowing is rarely necessary to finance building or equipment or land - the school could, instead, pay for it by reducing its (quasi)endowment. To do so, of course, would sacrifice returns on that financial wealth. If the school can borrow at a lower rate than the sacrificed earnings, it will be tempted to do so - simultaneously issuing debt and retaining financial assets in equal amount because what it pays in interest is less than what it earns. (Indeed, if that rate differential didn't exist, it's not

\footnotetext{
${ }^{7}$ Though an encouraging sign appears in the February 1998 issue of Consumer Reports where an opportunity cost is used explicitly - and identified as such - in a analysis of alternative ways to own or rent
} 
clear why a school would ever borrow, paying more on debt than it earns on the assets it protects by that borrowing.) So it seems wise to treat the "Interest on indebtedness," though nominally paying for the funds that built physical capital, as a strictly financial operation in which interest arbitrage earns revenues for the college - a transaction that has little to do with the actual costs of the use of capital. Interest, then, is fully recognized in the uniform opportunity cost of capital embedded in the calculated rental rate.

\section{Procedures:}

The procedural implication of all this is: (1) to eliminate all interest on indebtedness from reported operating costs and (2) to choose an opportunity cost of capital that will form a reasonable basis of a calculated rental rate.

Conceptually, the right opportunity cost rate to use is the return the school would earn if its financial assets were greater. But that - as the past few years have made very clear - is highly volatile over time as well as highly variable among alternative financial investments that differ in risk and return. So, unless the purpose of the cost calculations is to track short-term changes, including those driven by the financial markets, a rate averaged over a long period makes the most sense. I've used, for the IPEDS data, a five year average of the Federal Long Term Bond rate - which came to 8.55\% for the 1991 subsidy study - and for an individual school, a conservative smoothing of its endowment performance returns $-12 \%$ for the Williams cost estimates in the attachment. To generate comparable figures for, say, COFHE schools, agreement on something like a five (or ten) year average of NACUBO's reported endowment returns would produce uniformity and probably no more volatility than makes sense. What's important is (a) that the chosen opportunity cost be realistic in reflecting lost earning opportunities (b) fairly stable if educational changes are to be tracked over time and (c) consistent among schools if comparisons are to be made among them.

or buy a computer. 
Note, importantly, that even using something conservative like the long term US bond rate, the opportunity cost contributes more than three times as much to the yearly cost of capital services as does depreciation. So the current practice in FASB 117 of including depreciation while excluding opportunity costs seems to recognize physical capital service costs but still seriously understates their contribution to college costs.

And I understand that with next year's financial reports, FASB 117 will require that depreciation not be shown separately, but embedded in the activities reported in current operating expenses. That will make it impossible to follow the procedure I've followed in the past - and recommended above - of subtracting out those dubious depreciation estimates in order to replace them with the better ones as described above. But there are some gains from this new procedure - part, at least, of capital costs will be allocated among activities and it will still be possible to add in the larger and more important part of capital service cost as opportunity cost. So while $\mathrm{P}_{\mathrm{k}} \mathrm{K}(\delta+r)=\mathrm{P}_{\mathrm{k}} \mathrm{K} \delta+\mathrm{P}_{\mathrm{k}} \mathrm{Kr}$ is the complete rental rate and the depreciation part, $\mathrm{P}_{\mathrm{k}} \mathrm{K} \delta$, will be hidden in operating expenses, it will still be possible (and necessary) to recognize the larger, $\mathrm{P}_{\mathrm{k}} \mathrm{Kr}$, that is opportunity cost.

In the illustrative Williams spreadsheet included at the end, I've done high and low estimates of the cost of a year of education, the low one treating financial aid as price discounting and taking the conservative opportunity cost of capital (to get a cost of $\$ 55,609$ per student in 1995-6) and the high one treating financial aid as a cost of production and taking a $12 \%$ endowment return as the opportunity cost (to get $\$ 62,336$ ). The difference is large, but both are a far cry from the $\$ 34,322$ got by simply using E\&G spending per student.

\section{$\underline{4-\text { Two further complications: collections and accumulated deferred maintenance }}$}

Collections (and historic buildings) are harder to value meaningfully and hard to include in a blanket depreciation calculation. They do, typically, have a price and hence a replacement value (however appealing words like "invaluable" and "irreplaceable" 
may be), ${ }^{8}$ but that value may appreciate with the passage of time, rather than depreciate. The implication is that where they are a significant part of a school's wealth, collections and historic buildings may need to be recognized separately in replacement value estimates and in the depreciation component of rental rate.

The accumulation of deferred maintenance can be significant (Yale's announced \$1 billion a few years ago made that dramatically clear) and it has implications for calculation of the rental rate because it reduces the opportunity cost associated with a given replacement value of capital stock. Letting maintenance go for a year frees up money that can be spent elsewhere, including investment in earning assets. Deferring a good deal of maintenance will free up a good deal of resources, reducing the opportunity cost of a capital stock of a given replacement value. ${ }^{9}$ So the logic of opportunity cost applies not to the total replacement value of a capital stock, but to its replacement value net of accumulated deferred maintenance. In estimating the rental rate, then, the solution is simply to apply the opportunity cost calculation only to the net replacement value while still calculating the depreciation component of the rental rate on gross replacement value. For some schools, this will make little difference in the year's capital costs; for some it will make a lot. See note 6 above.

\section{Multiple Products, Cost Allocation and Joint Costs}

This is an issue on which I haven't a whole lot useful to say, not because it isn't important, but because its resolution is either terribly simple or terribly complicated and quite institution-specific. Either way, no great generalizations seem to help.

In schools like Williams and Swarthmore and Carleton, a single "product" is produced in the form of undergraduate education so, as noted earlier, it's safe to assume that virtually all current costs are incurred in production of that service. If resources are

\footnotetext{
${ }^{8}$ In 1983, Williams completed its acquisition of "irreplaceable" original copies of the three primary documents of US History - the Declaration of Independence, the Constitution, and the Bill of Rights - with the purchase, by an alumnus, of an original copy of the Declaration of Independence for \$412,500. So even these documents have a calculable replacement value.
} 
used for faculty research, for instance, they must be justified because of their effect directly or through faculty engagement and recruiting - on the quality of the undergraduate learning experience. Pretty simple.

But even a relatively uncomplicated university has serious problems of cost accounting as it produces undergraduate, graduate, and professional education, health services, research, serious service activities, athletic entertainment and TV programming, and hotel and restaurant services. Costs have to be allocated among these activities and joint costs have to be divided among them. This, it seems to me, is the most difficult problem facing the generation of meaningful estimates of the "cost of undergraduate education" in a university and the problem most in need of coordination of methodologies and assumptions among schools if their results are to be comparable.

My own cost estimates have met this problem in the national IPEDS data used for subsidy estimates, but there I was precluded from a very sophisticated - and certainly an individually tailored - accommodation by the absence of data. Because there were no data on the differences in tuition and financial aid that would have been necessary to generate different subsidy estimates, I even ignored differences in costs by level of instruction. Inserting the Howard Bowen cost weights (1.0 for Freshmen-Sophomores, 1.5 for upper class undergraduates, 2.1 for first year graduates, 2.5 for professional degree students, and 3.0 for advanced graduate students), without correction of tuition and financial aid, altered the subsidy estimates by Carnegie classification but not in unexpected ways so I dropped efforts to differentiate by level. On the other hand, I followed Duc Le To in dividing aggregate Educational and General spending into costs (a) directly related to instruction, (b) irrelevant to instruction (graduate and undergraduate) and (c) joint, and allocating joint costs on the basis of the relative dollar values of the other two. Capital costs were estimated for the whole of the institution, then allocated among functions ("products") in the same way. Both of these procedures were, I think, defensible, given the minimal detail of national data, but neither would seem well advised for an individual university or a set of universities seeking comparability. If

\footnotetext{
${ }^{9}$ The Appendix to Winston \& Lewis spells this out more patiently.
} 
there is a cooperative initiative to measure undergraduate costs, this is surely the area where shared methodology would make the greatest contribution.

\section{E. Student FTEs}

All of that estimated total undergraduate cost is divided by the number of students to get cost per student. Again, that's simple for Williams or Swarthmore but not so simple for a university with more part-time students who make different demands on the educational resources and incur different costs. The conventional way to convert from part-time to FTE students is simply by assuming that the average part-time student takes $1 / 3$ as many courses and resources as the full-time student, so dividing the number of part time students by 3 to get FTEs. For IPEDS data, that's fine, but for any individual school with a non-trivial proportion of part-time students, it might make sense to be more careful in the conversion, using credit hours or courses or some other and more sensitive measure.

\section{$\underline{\text { F. Subsidy calculations }}$}

As noted a few times above, much of my effort on college cost estimates has been to generate meaningful figures for student subsidies - the average student's educational cost less the price he pays, both net of grant aid. The total subsidy, in turn, is divided between a general subsidy that every student gets because his sticker price (gross tuition) is less than his educational costs, on the one hand, and any individual financial aid that further reduces the price he pays. ${ }^{10}$ The subsidy calculations are indifferent (because of reporting and fungibility problems) to the source of the "donative resources" that support those subsidies.

\footnotetext{
${ }^{10}$ Obviously (and conveniently), if financial aid is taken as a legitimate educational cost instead of a price discount, the difference that defines subsidy is unchanged as financial aid is added to both sides of the equation $S=C-P_{n}=C+A-P_{n}+A$ where $S$ is subsidy, $C$ is cost without financial aid, $A$, and $P_{n}$ is net price or sticker price less aid.
} 
The final two pages show the calculation of cost (and subsidy) for Williams. The first copies page 8, "Statements of Activities," from the 1996 Financial Report while the second maps those data into a spreadsheet that adds capital costs and calculates the resulting educational cost per student. The simplicity that a single-product college allows will be the envy of those trying to allocate costs for a university, but the major issues of financial aid and capital costs - and their importance - are usefully illustrated, I think. I've calculated costs, as noted earlier, using high (12\% opportunity cost and financial aid as a cost) and low estimates (8.5\% opportunity cost and financial aid as a price-discount). The mapping from financial statement to spreadsheet should be clear though, for reasons rehearsed at length above, the replacement value of capital and deferred maintenance had to be estimated independently of the school's Financial Report. ${ }^{11}$

\section{$\underline{\text { H. Conclusion }}$}

The purpose of this paper has been to address some of the major issues involved in measuring the yearly cost of an undergraduate education as they have emerged in recent studies of colleges' student subsidies. Two of the three stickiest elements - the treatment of financial aid and of the costs of buildings, equipment, and land - have been addressed more successfully than the third - the less general problem of disentangling undergraduate costs within a university that does a whole lot of things other than teach undergraduates.

\footnotetext{
${ }^{11}$ And typical of the murkiness surrounding such estimates, the $\$ 400$ million replacement value used there doesn't agree with a figure of $\$ 335$ million in Williams' recent reaccreditation report. But, importantly, both are a good deal closer to the truth than the $\$ 134$ million of book value reported in the Financial Report.
} 


\section{Williams College \\ Statements of Activities \\ For the year ended June 30,1996}

\begin{tabular}{lrrr} 
& Unrestricted & $\begin{array}{r}\text { Temporarily } \\
\text { Restricted }\end{array}$ & $\begin{array}{r}\text { Permanently } \\
\text { Restricted }\end{array}$ \\
OPERATING REVENUE, GAINS AND OTHER: & & & Total \\
Student tuition and fees & $\$ 41,042,563$ & $\$$ & $41,042,563$ \\
Sales and services of educational departments & $1,489,249$ & & $1,489,249$ \\
Auxiliary enterprises & $15,196,359$ & & $15,196,359$ \\
Special purpose grants expended & 975,287 & 975,287 \\
Gifts and grants & $9,632,606$ & $5,611,832$ & $15,244,438$ \\
Investment income & $17,161,361$ & $2,707,613$ & $19,868,974$ \\
Realized gains spent & $3,139,440$ & 126,328 & $3,265,768$ \\
Interest on loans receivable & 8,926 & & 8,926 \\
Other & 822,929 & & 822,929 \\
Net assets released from restrictions & $10,956,056$ & $(10,956,056)$ & 0 \\
\hline Total operating revenue, gains, and other & $100,424,776$ & $(2,510,283)$ & $97,914,493$
\end{tabular}

OPERATING EXPENSES AND OTHER:

\begin{tabular}{|c|c|c|}
\hline Instructional and research & $25,524,118$ & $25,524,118$ \\
\hline Academic support & $3,970,229$ & $3,970,229$ \\
\hline Student services & $6,979,599$ & $6,979,599$ \\
\hline Institutional support & $12,870,573$ & $12,870,573$ \\
\hline Operation and maintenance of plant & $6,891,072$ & $6,891,072$ \\
\hline Scholarships and fellowships & $9,099,760$ & $9,099,760$ \\
\hline Auxiliary enterprises & $13,059,803$ & $13,059,803$ \\
\hline Interest on indebtedness & $1,826,303$ & $1,826,303$ \\
\hline Depreciation & $8,409,626$ & $8,409,626$ \\
\hline Life income payments & $2,238,097$ & $2,238,097$ \\
\hline Other & 151.359 & 151,359 \\
\hline Total operating expenses and other & $91,020,539$ & $91,020,539$ \\
\hline Change in net assets from operating & $9,404,237$ & 6893,954 \\
\hline
\end{tabular}

\section{NON-OPERATING:}

\begin{tabular}{|c|c|c|c|c|}
\hline $\begin{array}{l}\text { Realized and unrealized gains on investments } \\
\text { Other losses }\end{array}$ & $\begin{array}{l}7,063,520 \\
(191,558)\end{array}$ & $53,096,489$ & $3,076,958$ & $\begin{array}{r}63,236,967 \\
(191,558)\end{array}$ \\
\hline Present value of future life income fund payments & 0 & $(683,903)$ & $(763,464)$ & $(1,447,367)$ \\
\hline Life income and endowment gifts & 0 & $1,168,100$ & $1,975,473$ & $3,143,573$ \\
\hline Gifts further designated & $(40,448)$ & $(54,568)$ & 95,016 & 0 \\
\hline Provision for loan guarantee & $(8.500,000)$ & & & $(8,500, \mathrm{OOO})$ \\
\hline Change in net assets from non-operating activities & $(1,668,486)$ & $53,526,118$ & $4,383,983$ & $56,241,615$ \\
\hline Total change in net assets prior to cumulative & & & & \\
\hline effect of accounting changes & $7,735,751$ & $51,015,835$ & $4,383,983$ & $63,135,569$ \\
\hline Cumulative effect of change in accounting principles & & 888,765 & $23,888,781$ & $24,777,546$ \\
\hline Total change in net assets & $7,735,751$ & $51,904,600$ & $28,272,764$ & $87,913,115$ \\
\hline Beginning net assets & $168,518,696$ & $237,432,107$ & $163,652,080$ & $569,602,883$ \\
\hline Ending net assets & $6,254,447$ & $289,336,707$ & $\$ 191,924,844$ & $\$ 657,515,998$ \\
\hline
\end{tabular}

The accompanying notes are an integral part of these financial statements. 


\section{Williams' Costs, Prices, and Subsidies: 1995-6}

Total Per Student

(2019)

\section{Operating Expenses}

Instructional \& res. (see Note below)

$25,524,118$

$3,970,299$

$6,979,599$

Student services

Institutional support

Operation \& mainten.

Auxiliary enterprises

TOTAL Operating Expenses

Scholarships \& Fellowships

TOTAL Operating Exp. w/aid

\section{Capital Service Costs}

Replacement Value Deferred Maintenance

Net replacement value

Deprec (2.5\%) on Replacement

Opportunity Cost on net repl val:

At $8.5 \%$

At $12 \%$

Capital Service Costs

At $8.5 \%$

At $12 \%$

\section{Cost: Aid is a Price Discount \\ At $8.5 \%$ \\ At $12 \%$}

Cost: Aid is an Educational Cost

At $8.5 \%$

At $12 \%$

PRICE:

Tuition, fees, \& auxiliary

Scholarships \& Fellowships

Net price

SUBSIDY: Aid is a Price Discount

At $8.5 \%$ opportunity cost

$400,000,000$

$12,000,000$

$388,000,000$

$10,000,000$

$32,980,000$

$46,560,000$

$42,980,000$

$56,560,000$

$112,275,464$

$125,855,464$

55,609

62,336

$121,375,224$

$134,955,224$

60,117

66,843

$56,238,922$

27,855

$9,099,760$

4,507

23,348

32,262

38,988

At $12 \%$ opportunity cost

Notes: Operation and maintenance assumed to include no renovation and repair. Both reported depreciation and interest are replaced by capital cost estimates.

An adjustment should have been made for $\$ 1,050,000$ of funded research trivial for Williams, but serious for most universities. With that correction and with replacement value of capital reduced proportionately, cost and student subsidy would have been reduced by $\$ 963$ or $1.5 \%$ and $2.4 \%$, respectively. 


\section{REFERENCES:}

Bowen, Howard R. The costs of higher education. (San Francisco: Jossey-Bass; 1980).

Bowen, William G. and David Breneman, "Student Aid: Price Discount or Educational Investment?" Brookings Review, Vol. 11, Winter 1993, pp. 28-31.

Carleton College, “Assuring Excellence," Inside Carleton: News of the Assuring Excellence Campaign, Summer 1997.

Dunn, John A., Jr. Financial planning guidelines for facilities renewal and adaptation. (Ann Arbor: The Society for College and University Planning; 1989)

Hansmann, Henry "The Role of Nonprofit Enterprise," Chapter 3 in Susan RoseAckerman. The Economics of Nonprofit Institutions. (New York: Oxford University Press; 1986).

Hicks, J. R. Value and Capital: An Inquiry into Some Fundamental Principles of Economic Theory. (Oxford; at The Clarendon Press; 1939).

Lewis, Ethan G., and Gordon C. Winston, "Subsidies, Costs, Tuition, and Aid in US Higher Education: 1986-87 to 1993-94," Williams Project on the Economics of Higher Education Discussion Paper No. 41r, April 1997.

Probasco, Jack, "Crumbling campuses: What are the real costs?" NACUBO Business Officer, Vol. 25, No. 5, November 1991, pp. 48-51.

Rothschild, Michael and Lawrence J. White, "The Analytics of Pricing in Higher Education and Other Services in Which Customers are Inputs," Journal of Political Economy, Vol. 103, June 1995, pp. 573-86.

To, Duc-Le, "Estimating the Cost of a Bachelor's Degree: An Institutional Cost Analysis," Washington DC: Office of Educational Research and Improvement, US Department of Education, March 1987

Winston, Gordon C., "The Necessary Revolution in Financial Accounting," Planning for Higher Education, Vol. 20, No. 4, Summer 1992, pp. 1-16. (DP-15).

Winston, Gordon C. "Organizing Economic Information for Colleges and Universities: An Alternative to Fund Accounting," Williams Project on the Economics of Higher Education Discussion Paper No. 15, November 1991, (published as "New dangers in old traditions: The reporting of economic performance in colleges and universities," Change, Vol. 25, No. 1, January/February 1993, pp.18-23). 
Winston, Gordon C. "The Capital Cost Conundrum," The NACUBO Business Officer, June 1993, pp. 22-27. (DP-14).

Winston, Gordon C., "Maintaining Collegiate Wealth: Global Accounts, Fund Accounting, and Rules of Thumb," Williams Project on the Economics of Higher Education Discussion Paper No. 22, December 1993.

Winston, Gordon C., "A Note on the Logic and Structure of Global Accounting," Williams Project on the Economics of Higher Education Discussion Paper No. 23, January 1994.

Winston, Gordon C., and Ivan C. Yen, "Costs, Prices, Subsidies, and Aid in U.S. Higher Education," The Williams Project on the Economics of Higher Education, Discussion Paper No. 32, July 1995.

Winston, Gordon C., "The Economic Structure of Higher Education: Subsidies, Customer-Inputs, and Hierarchy," Williams Project on the Economics of Higher Education Discussion Paper No. 40, November 1996.

Winston, Gordon C., and Ethan G. Lewis, "Physical Capital and Capital Costs in US Colleges and Universities: 1993," Williams Project on the Economics of Higher

Education Discussion Paper No. 35, February, 1996 (published as "Physical Capital and Capital Service Costs in U.S. Colleges and Universities: 1993," Eastern Economic Journal, Vol. 23, No. 2, Spring 1997, pp. 165-89). 